\title{
Non-Classic Congenital Adrenal Hyperplasia
}

National Cancer Institute

\section{Source}

National Cancer Institute. Non-Classic Congenital Adrenal Hyperplasia. NCI Thesaurus.

Code C131442.

A milder form of cong enital adrenal hyperplasia characterized by decreased activity of an enzyme in the steroidogenic pathway, typically presenting later in life, that does not require life-long cortisol replacement. 